\title{
Comparative Studies on Triclabendazole and Mirazid in Guinea Pigs Experimentally Infected with Fasciola gigantica El-Boshy $\mathrm{ME}^{1 *}$, Husien $\mathrm{SH}^{4}$, Fatma MA², Engy $\mathrm{FR}^{2}$ and Osama $\mathrm{AM}^{3}$
}

${ }^{1}$ Department of Laboratory Medicine, Umm al Qura University, Makkah, Saudi Arabia

${ }^{2}$ Department of Clinical Pathology, Mansoura University, Egypt

${ }^{3}$ Department of Clinical Pathology, Suez Canal University, Egypt

${ }^{4}$ Department of Pathology, Mansoura University, Egypt

\begin{abstract}
Forty Guinea pigs (1-2 month old) were divided into 4 equal groups to study the efficacy of treatment of facioliasis with triclabendazole (TCBZ) and mirazid. Group (Gp.1) was the control, GPs (2-4) were orally inoculated with 20 Fasciola gigantic metacercariae (FGM) for each as a single dose by using stomach tube. Gps ( 3 and 4 ) were treated orally, with TCBZ, as a single dose $(36 \mathrm{mg} / \mathrm{Kg} \mathrm{Bw})$ and mirazid $200 \mathrm{mg} / \mathrm{Kg} \mathrm{Bw}$ for six successive days respectively. The drugs were administered in the 8th week post-infection to evaluate their efficacy against adult stages of Fasciola gigantica. Blood samples were collected at the end of the $1^{\text {st }}$ and $2^{\text {nd }}$ week post treatment for hematological and serum biochemical examination. TCBZ treated groups (GP 3) showed macrocytic hypochromic anemia, which disappeared at the end of the $2^{\text {nd }}$ week post treatment. Heterophilia, esinophilia and lymphopenia were encountered in non treated group (GP 2) and mirazid treated group (GP 4). The liver transaminase (ALT, AST), gamma glytamyl transferase (GGT) and alkaline phosphatase (ALP) as well as total bilirubin, urea and creatinine, were elevated while serum albumin was decreased in GP (2) and returned to the normal value in GP (3) and GP (4) after two weeks post-treatment. It could be concluded that; the triclabendazole is more effective than mirazid in the treatment of Fasciola gigantica infection. Further research should be done for more precise knowledge about the efficacy of mirazid as a fasciolicidal drug.
\end{abstract}

Keywords: Triclabendazole; Mirazid; Guinea pigs; Fasciola gigantica

\section{Introduction}

Distomiasis is among the most important parasitic diseases that affect the domesticated and wild animal besides man all over the world. The disease causes significant economic losses due to the high financial losses through the great expenses on therapy, and to liver condemnation. Moreover the production is hindered due to the mortalities and the lower production of milk, meat and wool in addition to the decrease body gain and impaired fertility [1].

Triclabendazole (TCBZ), benzimidazole antihelmintic drug, unlike other broad spectrum benzimidazole drugs it shows only marginal activity against liver fluke, its efficacy appears to be restricted to both adult and juvenile flukes of $F$. hepatica, F. gigantica and F. magna. TCBZ, produces a gradual suppression in the activity of the flukes unlike other benzimidazole which makes prolonged stimulation before the movement is finally declined [2].

Mirazid is a new herbal antihelmintic drug formed from myrrh extract that is derived from Commiphora molmol (C. molmol) tree, family burseraceae. It's one of the oldest known medicinal plants used by ancient Egyptians for medical purposes as well as in mummification. Recently it had been licensed for medical use in Egypt as a trematodicidal drug with high efficacy and safety. As it is well tolerated with a wide margin of safety for the liver, kidneys, hemopoietic system and chromosomes. It is non-mutagenic besides it can be repeated for a long period [3].

This work aimed to compare the efficacy of TCBZ and mirazid, in the treatment of the Fasciola gigantica in Guinea pigs.

\section{Materials and Methods}

\section{Experimental animals}

Thirty two Guinea pigs, 1-2 month old of both sexes were obtained from Helwan farm of Laboratory Animals (Ministry of Public Health). The animals were kept in galvanized zinc plate cages under strict hygienic conditions. The animals were ensured freedom from parasitic infection, through a regular parasitological examination. The daily requirement of ascorbic (50 $\mathrm{mg} /$ liter of drinking water) was supplied throughout the experiment according to [4].

\section{The metacercariae}

Fasciola gigantic a metacercariae were obtained from the Parasitology Department of Theodor Bilharz, Research Insitiute, Imbaba, Egypt and was examined for the viability. The infective dose for each animal was prepared by counting metacercariae on the polyethylene strips.

\section{Drugs}

Mirazid: It was obtained as a soft gelatin capsule containing an oleo-resin purified Commiphora molmol extract as $300 \mathrm{mg}$ (Pharco Pharmaceuticals, Alexandria, Egypt). The active ingredients of the different fractions extract of Commiphora myrrha are sesquiterpenes, diterpenes, diterpenic acids, sandaracopimaric acid and abietic acid [5].

*Corresponding author: El-Boshy ME, Professor of Diagnostic Chemistry, Faculty of Applied Medical Science, Laboratory Medicine, Makka, Saudi Arabia, Tel: 00966563025297; E-mail: dr_elboshy@yahoo.com

Received November 10, 2014; Accepted January 07, 2015; Published January 13, 2015

Citation: El-Boshy ME, Husien SH, Fatma MA, Engy FR, Osama AM (2015) Comparative Studies on Triclabendazole and Mirazid in Guinea Pigs Experimentally Infected with Fasciola gigantica. J Bioanal Biomed 7: 013-017. doi:10.4172/1948593X.1000117

Copyright: (c) 2015 El-Boshy ME, et al. This is an open-access article distributed under the terms of the Creative Commons Attribution License, which permits unrestricted use, distribution, and reproduction in any medium, provided the original author and source are credited. 
Triclabendazole: Fasinex (10\%) a white color suspension prepared for oral uses (Novartis.Co. Switzerland).

\section{Experimental Design}

The experiment was conducted on 32 Guinea pigs, 1-2 month age, after acclimatization for 15 days in cages; the animals were divided into four equal groups. GP (1) was the control. Each animal in GPs (2-4) was orally inoculated with $20 \mathrm{FGM}$ as a single dose by using stomach tube. GP (2) was experimental control, infected and non-treated. GP (3) was orally treated with TCBZ at a dose $36 \mathrm{mg} / \mathrm{Kg} \mathrm{Bw}$ and GP (4) was orally treated with mirazid $(200 \mathrm{mg} / \mathrm{Kg} \mathrm{Bw})$ for six successive days in the early morning on an empty stomach, according to the dose carried out by Soliman et al [6] and adjusted based on the animal body weight [7]. The drugs were administered at the end of the $8^{\text {th }}$ week post infection to evaluate their efficacy against adult stages of Fasciola gigantica. Eight Guinea pigs were randomly picked up from each group $1^{\text {st }}$ and $2^{\text {nd }}$ week post treatment. Blood samples were individually collected by heart-puncture for hematological examination (RBC count, hemoglobin concentration, PCV value, total WBC count and differential leukocyte count) according to [8-10] respectively. Serum chemistry (ALT, AST, ALP, total bilirubin, total protein, albumin, urea and creatinine were done using commercial diagnostic kits obtained from Spine React Spanish Co., while the gamma glutamyltransferase (GGT) was determined by using readymade kits provided by Emapole, (Poland). Fecal samples were collected at the end of the $8^{\text {th }}$ week post- infection and examined for fluke eggs by the sedimentation method according to [11].

\section{Statistical analysis}

The haematological values and serum biochemical parameters were analyzed by analysis of variance (ANOVA) using State View, [12] for windows. Two groups were significantly different if $\mathrm{P}$ was statistically lower than 0.05

\section{Results}

The erythrogram revealed macrocytic hypochromic in infected non-treated group as well as the infected and treated groups at on week post treatment when compared with the control group, while those parameters returned to the normal two weeks post treatment (Tables 1 and 2). Regarding to the leukogram in the investigated groups, there was heterophilia, eosinophilia and lymphopenia in both infected non-treated and mirazid treated groups as compared with the control group, while the leukogram return to normal at 2 weeks post treated with TCBZ (Tables 3 and 4).

The disorders of liver functions, documented in our study of elevated liver enzymes, total bilirubin and decreased serum albumin in infected non-treated group as compared with the control group, while the liver functions were normal in TCBZ treated group 2 week post treatment (Tables 5 and 6). The liver enzymes, ALT, AST, ALP and

Table 1: Studeis on erythrogram parameters (mean \pm s.e), one week post treatment in Guinea pigs experimentally infected with, Fasciola gigantica.

\begin{tabular}{|c|c|c|c|c|c|}
\hline Group & $\begin{array}{c}\mathbf{R B C} \\
\mathbf{1 0} / \mathbf{\mu L}\end{array}$ & $\begin{array}{c}\mathbf{H b} \\
\mathbf{g} / \mathbf{d L}\end{array}$ & $\begin{array}{c}\mathbf{P C V} \\
\mathbf{\%}\end{array}$ & $\begin{array}{c}\mathbf{M C V} \\
\mathbf{f l}\end{array}$ & $\begin{array}{c}\mathbf{M C H} \\
\mathbf{p g}\end{array}$ \\
\hline 1 & $5.45^{\mathrm{b}} \pm 0.42$ & $15.54 \mathrm{~b} \pm 1.12$ & $40.51 \mathrm{~b} \pm 1.25$ & $74.32 \mathrm{~b} \pm 3.51$ & $28.58 \pm 1.23$ \\
\hline 2 & $4.25^{\mathrm{a}} \pm 0.35$ & $11.01 \mathrm{a} \pm 0.81$ & $36.9 \mathrm{a} \pm 0.75$ & $86.8 \mathrm{a} \pm 4.12$ & $25.9 \pm 1.12$ \\
\hline 3 & $4.31^{\mathrm{a}} \pm 0.32$ & $11.19 \mathrm{a} \pm 0.78$ & $36.7 \mathrm{a} \pm 0.80$ & $85.2 \mathrm{a} \pm 4.01$ & $26.1 \pm 1.18$ \\
\hline 4 & $4.71^{\mathrm{b}} \pm 0.45$ & $12.86 \mathrm{~b} \pm 1.32$ & $38.7 \mathrm{~b} \pm 1.47$ & $82.26 \mathrm{~b} \pm 3.58$ & $27.3 \pm 1.42$ \\
\hline
\end{tabular}

The same Column not followed by the same letter differs significantly $(P<0.05)$

Table 2: Studeis on leukogram parameters (mean \pm s.e), one week post treatment in Guinea pigs experimentally I infected with, Fasciola gigantica.

\begin{tabular}{|c|c|c|c|c|c|c|}
\hline Group & $\begin{array}{c}\text { TLC } \\
10^{3} / \mu \mathrm{L}\end{array}$ & $\begin{array}{l}\text { Hetrophil } \\
10^{3} / \mu \mathrm{L}\end{array}$ & $\begin{array}{l}\text { Esinophil } \\
10^{3} / \mu \mathrm{L}\end{array}$ & $\begin{array}{l}\text { Basophil } \\
10^{3} / \mu \mathrm{L}\end{array}$ & $\begin{array}{c}\text { Lymphocyte } \\
10^{3} / \mu \mathrm{L}\end{array}$ & $\begin{array}{l}\text { Moncy } \\
10^{3} / \mu \mathrm{L}\end{array}$ \\
\hline 1 & $9.30^{\mathrm{a}} \pm 0.57$ & $3.02^{b} \pm 0.21$ & $0.56^{b} \pm 0.21$ & $0.04^{a} \pm 0.02$ & $4.97^{a} \pm 0.54$ & $0.71^{\mathrm{a}} \pm 0.11$ \\
\hline 2 & $10.65^{a} \pm 0.42$ & $4.77^{a} \pm 0.43$ & $2.03^{a} \pm 0.51$ & $0.08^{a} \pm 0.08$ & $3.19^{b} \pm 0.51$ & $0.69^{a} \pm 0.09$ \\
\hline 3 & $9.45^{\mathrm{a}} \pm 0.78$ & $3.28^{b} \pm 0.11$ & $0.59^{b} \pm 0.27$ & $0.06^{a} \pm 0.06$ & $4.77^{a} \pm 0.54$ & $0.75^{a} \pm 0.15$ \\
\hline 4 & $10.39^{a} \pm 1.01$ & $4.65^{a} \pm 0.39$ & $2.01^{a} \pm 0.21$ & $0.05^{a} \pm 0.05$ & $3.05^{b} \pm 0.59$ & $0.63^{a} \pm 0.13$ \\
\hline
\end{tabular}

The same Column not followed by the same letter differs significantly $(P<0.05)$

Table 3: Studeis on erythrogram parameters (mean \pm s.e), two week post treatment in Guinea pigs experimentally infected with, Fasciola gigantica.

\begin{tabular}{|c|c|c|c|c|c|c|}
\hline Group & $\begin{array}{c}\text { RBC } \\
10^{6} / \mu \mathrm{L}\end{array}$ & $\begin{array}{l}\mathrm{Hb} \\
\mathrm{g} / \mathrm{dL}\end{array}$ & $\begin{array}{c}\text { PCV } \\
\%\end{array}$ & $\begin{array}{c}\text { MCV } \\
\text { FI }\end{array}$ & $\begin{array}{c}\mathrm{MCH} \\
\mathrm{Pg}\end{array}$ & $\underset{\%}{\mathrm{MCHC}}$ \\
\hline 1 & $5.41^{\mathrm{a}} \pm 0.47$ & $14.75^{\mathrm{a}} \pm 1.03$ & $39.2^{a} \pm 1.32$ & $72.5^{a} \pm 3.32$ & $27.3^{a} \pm 1.16$ & $37.91^{a} \pm 1.68$ \\
\hline 2 & $4.76^{a} \pm 0.39$ & $12.92^{\mathrm{a}} \pm 1.09$ & $37.1^{a} \pm 0.98$ & $77.9^{a} \pm 4.85$ & $27.2^{\mathrm{a}} \pm 0.91$ & $34.91^{\mathrm{a}} \pm 1.59$ \\
\hline 3 & $4.71^{a} \pm 0.40$ & $12.38^{a} \pm 0.81$ & $37.3^{a} \pm 0.79$ & $79.19^{a} \pm 5.03$ & $26.3^{a} \pm 1.05$ & $33.12^{\mathrm{a}} \pm 1.81$ \\
\hline 4 & $4.95^{\mathrm{a}} \pm 0.41$ & $13.17^{a} \pm 1.12$ & $38.9^{a} \pm 1.47$ & $78.6^{a} \pm 4.15$ & $26.6^{a} \pm 1.28$ & $34.41^{\mathrm{a}} \pm 1.75$ \\
\hline
\end{tabular}

The same Column not followed by the same letter differs significantly $(P<0.05)$

Table 4: Studeis on leukogram parameters (mean \pm s.e), two week post treatment in Guinea pigs experimentally infected with, Fasciola gigantica

\begin{tabular}{|c|c|c|c|c|c|c|}
\hline Group & $\begin{array}{c}\text { TLC } \\
10^{3} / \mu \mathrm{L}\end{array}$ & $\begin{array}{l}\text { Hetrophil } \\
10^{3} / \mu \mathrm{L}\end{array}$ & $\begin{array}{l}\text { Esinophil } \\
10^{3} / \mu \mathrm{L}\end{array}$ & $\begin{array}{l}\text { Basophil } \\
10^{3} / \mu \mathrm{L}\end{array}$ & $\begin{array}{l}\text { Lymphocyte } \\
10^{3} / \mu \mathrm{L}\end{array}$ & $\begin{array}{l}\text { Moncyte } \\
10^{3} / \mu \mathrm{L}\end{array}$ \\
\hline 1 & $9.26^{a} \pm 0.51$ & $2.91^{b} \pm 0.49$ & $0.51^{c} \pm 0.19$ & 0.00 & $5.20^{a} \pm 0.43$ & $0.64^{a} \pm 0.12$ \\
\hline 2 & $9.72^{a} \pm 0.59$ & $3.69^{a} \pm 0.42$ & $1.95^{\mathrm{a}} \pm 0.35$ & $0.12 \pm 0.08$ & $4.29^{b} \pm 0.51$ & $0.67^{a} 0.08$ \\
\hline 3 & $9.79^{a} \pm 0.53$ & $3.28^{b} \pm 0.41$ & $0.61^{c} \pm 0.27$ & $0.08 \pm 0.08$ & $5.13^{a} \pm 0.49$ & $0.69^{a} \pm 0.13$ \\
\hline 4 & $10.01^{a} \pm 0.61$ & $3.99^{a} \pm 0.36$ & $0.88^{b} \pm 0.17$ & 0.00 & $4.48^{b} \pm 0.57$ & $0.75^{a} \pm 0.10$ \\
\hline
\end{tabular}

The same Column not followed by the same letter differs significantly $(P<0.05)$ 
Table 5: Serum biochemical profiles (mean \pm s.e), one week post treatment in Guinea pigs experimentally infected with, Fasciola gigantica.

\begin{tabular}{|c|c|c|c|c|c|c|c|c|c|c|c|c|c|}
\hline Groups & ALT U/L & AST U/L & GGT U/L & ALP U/L & T. Bili. mg/dl & T. P. gm/dl & Alb. gm/dl & Urea mg/dl & Creat. mg/d \\
\hline 1 & $15.6^{\mathrm{c}} \pm 1.41$ & $24.2^{\mathrm{c}} \pm 2.32$ & $16.25^{\mathrm{b}} \pm 1.19$ & $14.32^{\mathrm{c}} \pm 1.31$ & $0.44^{\mathrm{b}} \pm 0.07$ & $5.56^{\mathrm{b}} \pm 0.35$ & $3.05^{\mathrm{b}} \pm 0.28$ & $45.59 \pm 4.42$ & $0.65^{\mathrm{b}} \pm 0.05$ \\
\hline 2 & $34.9^{\mathrm{a}} \pm 1.85$ & $49.29^{\mathrm{a}} \pm 4.3$ & $28.93^{\mathrm{a}} \pm 1.45$ & $31.23^{\mathrm{a}} \pm 1.51$ & $0.89^{\mathrm{a}} \pm 0.08$ & $4.52^{\mathrm{a}} \pm 0.31$ & $2.12^{\mathrm{a}} \pm 0.25$ & $54.2 \pm 5.62$ & $0.86^{\mathrm{a}} \pm 0.07$ \\
\hline 3 & $24.5^{\mathrm{b}} \pm 1.19$ & $32.5^{\mathrm{b}} \pm 3.01$ & $23.45^{\mathrm{a}} \pm 1.51$ & $16.2^{\mathrm{c}} \pm 1.32$ & $0.54^{\mathrm{b}} \pm 0.07$ & $4.69^{\mathrm{b}} \pm 0.39$ & $2.24^{\mathrm{a}} \pm 0.27$ & $50.78 \pm 5.44$ & $0.81 \mathrm{a}^{\mathrm{b}} \pm 0.09$ \\
\hline 4 & $26.2^{\mathrm{b}} \pm 1.12$ & $30.3^{\mathrm{b}} \pm 2.99$ & $23.45^{\mathrm{a}} \pm 1.51$ & $25.9^{\mathrm{b}} \pm 1.25$ & $0.51^{\mathrm{b}} \pm 0.06$ & $4.81^{\mathrm{b}} \pm 0.41$ & $2.20^{\mathrm{a}} \pm 0.26$ & $49.35 \pm 6.01$ & $0.74 \mathrm{a}^{\mathrm{b}} \pm 0.06$ \\
\hline
\end{tabular}

T.Bili; Total Bilirubin, T.P, Total Protein, Alb, Albumin, Creat, Creatinine

The same Column not followed by the same letter differs significantly $(P<0.05)$

Table 6: Serum biochemical profiles (mean \pm s.e), two week post treatment in Guinea pigs experimentally infected with, Fasciola gigantica

\begin{tabular}{|c|c|c|c|c|c|c|c|c|c|}
\hline Groups & $\begin{array}{l}\text { ALT } \\
\text { U/L }\end{array}$ & $\begin{array}{l}\text { AST } \\
\text { U/L }\end{array}$ & $\begin{array}{l}\text { GGT } \\
\text { U/L }\end{array}$ & $\begin{array}{l}\text { ALP } \\
\text { U/L }\end{array}$ & $\begin{array}{l}\text { T.Bili. } \\
\mathrm{mg} / \mathrm{dl}\end{array}$ & $\begin{array}{l}\text { T. P. } \\
\text { gm/dl }\end{array}$ & $\begin{array}{l}\text { Alb. } \\
\text { gm/dl }\end{array}$ & $\begin{array}{l}\text { Urea } \\
\mathrm{mg} / \mathrm{dl}\end{array}$ & $\begin{array}{l}\text { Creat. } \\
\text { mg/d }\end{array}$ \\
\hline 1 & $13.9 b \pm 1.21$ & $23.8^{b} \pm 2.14$ & $17.19^{c} \pm 1.23$ & $15.04^{c} \pm 1.29$ & $0.49^{b} \pm 0.06$ & $5.62^{a} \pm 0.39$ & $3.18^{\mathrm{b}} \pm 0.27$ & $42.32^{b} \pm 4.01$ & $0.61^{b} \pm 0.06$ \\
\hline 2 & $32.6 a \pm 1.70$ & $51.9^{\mathrm{a}} \pm 4.7$ & $29.82^{a} \pm 1.34$ & $34.95^{a} \pm 1.42$ & $0.91^{\mathrm{a}} \pm 0.09$ & $4.75^{a} \pm 0.42$ & $2.24^{a} \pm 0.29$ & $59.18^{a} \pm 5.14$ & $0.94^{a} \pm 0.08$ \\
\hline 3 & $16.4 c \pm 1.26$ & $26.2^{c} \pm 2.15$ & $18.21^{c} \pm 1.38$ & $16.83^{c} \pm 1.27$ & $0.52^{b} \pm 0.06$ & $5.35^{a} \pm 0.37$ & $2.83^{\mathrm{ab}} \pm 0.24$ & $41.85^{b} \pm 4.06$ & $0.73^{b} \pm 0.08$ \\
\hline 4 & $22.7 b \pm 1.02$ & $34.1^{b} \pm 2.35$ & $22.15^{\mathrm{b}} 1.32$ & $25.75^{b} \pm 1.19$ & $0.50 b \pm 0.05$ & $5.41^{\mathrm{a}} \pm 0.42$ & $2.92^{\mathrm{ab}} \pm 0.27$ & $42.49^{b} \pm 3.95$ & $0.70^{b} \pm 0.07$ \\
\hline
\end{tabular}

T.Bili; Total Bilirubin, T.P, Total Protein, Alb, Albumin, Creat, Creatinine

The same column not followed by the same letter differs significantly $(P<0.05)$

GGT were significantly increased in mirazid treated group at 2 weeks post-treatment when compared with the control and significantly decreased as compared with the infected group.

Regarding to renal function tests, the creatinine and urea were significantly elevated in infected non-treated group when compared with the control group. In the treated groups (TCBZ \& mirazid) the renal function tests were non significant difference when compared with control group as displayed in the Tables 5 and 6.

\section{Discussion}

Facioliasis is disease caused by a trematode that invades the hepatic parenchyma and bile ducts of ruminants and other mammals, causing significant economic losses such as mortalities, low production of meat, milk and wool as well as reduced weight gain and impaired fertility [13].

The erythrogram result showed regenerative macrocytic hypochromic anemia in the infected non-treated groups. Such regenerative anemia could be the result of traumatic lesions induced during the migration of the juvenile flukes in the hepatic parenchyma, causing hepatobilary hemorrhage till establishing themselves in the bile ducts [14]. Moreover the anemia may be a result of the hepatotoxic effect of the worm metabolites (proline) which induces hemolysis and impaired erythropoiesis [15]. The anemia was a common feature during the late stage of infection, which partially agrees with Waweru et al. [16] who reported that the common cause of anemia in two breeds of sheep infected with Fasciola gigantica at late stage was the heamatophagic nature of the parasite in the bile duct. Also agree with Yadav et al., [14] who found that the anemia started to occur from the $7^{\text {th }}$ week PI in bovine calves and from the $6^{\text {th }}$ week PI in buffalo calves.

The triclabendazole is a benzimidazole anthelmintic which was reported to have a specific flukicidal effect against the mature and immature stages of Fasciola hepatica and Fasciola gigantica in the small and large domesticated ruminants [17]. The infected group and treated with TCBZ showed anemia 2 month PI and for one week post treatment, then disappeared after two weeks of treatment as the drug eliminated most of the late stages of the immature and mature flukes. Consequently, there was a blood loss through the hepatobilary hemorrhage [18]. Moreover, the TCBZThis reported that the produced a significant increase in $\mathrm{RBC}$ at the $3^{\text {rd }}$ week post treatment of sheep infected with fascioliasis [19].
Heterophilia, lymphopenia and insignificant change in the monocytes were observed in the Guinea pigs of infected non-treated group one week post treatment. These changes could be attributed to stress condition caused by early migration of the flukes in the hepatic parenchyma and the associated hemorrhage. The leukocytosis has been reported in different species of fascioliasis sheep [20,21]. Also the decrease in the lymphocytic response may be due to decreased production of IL- 2 produced by the splenocytes of the infected rats as it is essential for the lymphocytes development and growth [22]. Meanwhile, our result are not in accordance with Bashandy et al. [21] and Venguest et al. [23] who found lymphocytosis and monocytosis in sheep and fallow deer infected with Fasciola gigantica and Fasciola hepatica respectively.

Eosinophils provide a defense against the larvae of parasitic worms and unicellular organisms [24]. The eosinophil granules contain a substance called the Major Basic Protein (MBP) which is toxic to many parasitic larvae [25]. The eosinophils have surface receptors for the antibody immunoglobulin E (IgE), these receptors are believed to be of importance in fighting the parasitic infection [26]. Eosinophilia that continued till the end of the experiment was the most predominant leukogram change in infected non-treated group (GP2). Similarly, to our resort, the eosinophilia in the current work could be attributed to the increased IL-5 from Th2 cytokines that contribute to the growth and differentiation of the eosinophils [22,27]. Eosinophilia was seen in rats and mice that were injected with Fasciola hepatica antigen as a result of increased eosinophilic precursors in the bone marrow [28].

The leukogram of infected and treated with TCBZ (GP, 3) showed eosinophilia, returned rapidly to the normal level after treatment. TCBZ eliminated most of the immature and mature flukes, reducing the hematological alterations to take place in fascioliasis [18]. This is indicated that the drug has high efficacy against immature and mature flukes. Similarly, several authors documented the efficacy of TCBZ in the treatment of fascioliasis $[18,29,30]$.

The eosinophilia remained even after the $2^{\text {nd }}$ week post treatment in the mirazid treatment group (GP, 4). This indicates that the mirazid is not highly effective against the Fasciola gigantica. This agrees with Fatem and Soheir [31] who reported that there is a considerable doubt about the efficacy of this drug in the treatment of schistosoma species. On the other hand, the fasciolicidal effect of mirazid in the patient endemic area with fasioliasis approved by significant decreasing eosinophilia after treatment with mirazid $[3,32]$. 
The liver transaminase enzymes (ALT \& AST) are used to evaluate the liver damage during experimental infection of Fasciola gigantica in Guinea pigs. The ALT and AST were significantly increased in the infected group till the end of the experiment [23]. Such elevation is an indicator for the hepatocyte degeneration and fibrosis besides blockage of the bile ducts by migration of the juvenile flukes during the first stage of infection [33]. Similar results were reported by many authors who studied fascioliasis in different species $[23,34,35]$. The GGT and ALP levels were significant increased in infected non-treated group $(G P, 2)$. As the GGT and ALP are located in the bile duct epithelium, so its elevation is considered as a biomarker of a cholestatic effect and hyperplastic cholangitis [36]. Our results are in agreement with several authors, reported biliary hyperplasia in different animal species suffering from fascioliasis $[23,33,36]$.

The liver enzymes ALT, AST, ALP and GGT were returned to the normal level in TCBZ group, while were significantly increased in mirazid treated group when compared with control. This means that the mirazid is less effective against the fascioliasis compared with TCBZ. This result agrees with Fatem and Sohaire [31], who doubted the efficacy of mirazid in the treatment of schistosomiasis in hamsters. Moreover, the GGT and ALP returned to the normal level in patients of fascioliasis 3 month post treatment [37]. Regarding to the TCBZ treatment, our results are in accordance with $[19,20]$, who reported that the alteration in the liver enzyme which returned to the normal level four weeks post-treatment (PT) with TCBZ. Such results disagreed with [38], who found that the GGT enzyme remained elevated 24 days PT in sheep. This difference may be attributed to the difference in species.

The bilirubin level in infected non-treated group (GP, 2) revealed that the total bilirubin was significantly increased till the end of the experiment. The hyperbilirubinemia occurred as a result of an increased production rate of the bilirubin either from increase catabolism of cytochrom $\mathrm{P} 450$ which represents a high percentage of the total heme synthesized in the liver [39] and or from an increased erythrocyte degradation due to hematophagia by the flukes .Our results agree with [40], who studied the effect of experimental fascioliasis on the bilirubin metabolism in rats. The total bilirubin, were insignificantly changed in the treated groups (GPs, 3\&4) as drug eliminated most of the immature and mature flukes. This gets along with our results about the inefficacy of mirazid against the immature stages when compared with the adult ones.

The total protein and albumin were decreased in the infected group compared with control. The hypoproteinemia in the present work could be the result of anorexia and inefficient food utilization that accompanied the fluke infection, or from the hepatic damage caused by the migration of the flukes. The hypoalbuminemia could be due to the inhibition of its synthesis or the increased loss or breakdown of albumin [41]. Our results agree with [38,35], who studied fascioliasis in naturally infected sheep and cattle respectively. The alteration in the serum protein returned rapidly to the normal level after treatment with TCBZ and mirazid.

The elevation of urea and creatinine levels in infected none treated (GP.2) could be as a result of renal injury caused by deposition of granular and pesudolinear IGg fasciola antigen in the mesangial region of the glomeruli, leading to membranoproliferative and mesangioproliferative glomerulonephritis in bovine fascioliasis $[1,36]$. The urea and creatinine were insignificantly changed two weeks after treatment with TCBZ and mirazid. Ahamed et al. [37] reported that the urea and creatinine levels in patient with fascioliasis were within the normal range before and after treatment with mirazid.

\section{Conclusion}

It could be concluded that; the triclabendazole is more effective than mirazid in the treatment of Fasciola gigantica infestation. Further research should be done for more precise knowledge about the efficacy of mirazid as antifasciolicidal drug.

\section{References}

1. Marques ST, Scroferneker ML, Edelweiss MI (2005) Kidney pathology in cattle naturally infected by Fasciola hepatica. Israel Veterinary Medical Association 60.

2. Dalton JP (1998) Fascioliasis. UK at University Press, Cambridge

3. Massoud AM, EL-Ashmawy IM, Hemeda SA, Salama OM (2000) Hematological chromosomal and teratogenic studies of a new schistosomicidal agent derived from myrrh. Alex J Pharmacol Sci 14: 61-68.

4. Sarah W, Maggie L (2003) Handbook of Laboratory Animal Management and Welfare. ( $3^{\text {rd }}$ edition) lowa State Press, USA.

5. Su S, Wang T, Duan J, Zhou W, Hua Y, et al. (2001) Anti-inflammatory and analgesic activity of different extracts of Commiphora myrrha. Journal of Ethnopharmacology 134: 251-258.

6. Soliman OE, El-Arman M, Abdul-Samie ER, El-Nemr HI, Massoud A (2004) Evaluation of myrrh (Mirazid) therapy in fascioliasis and intestinal schistosomiasis in children: immunological and parasitological study. J Egypt Soc Parasitolb 34: 941-966.

7. Paget GE, Barnes JM (1964) Evaluation of Drug Activities : Pharmacometrics, Laurence and Bacharach. Academic Press, New York 133-166.

8. Feldman BG, Zinkl JG, Jain NC (2000) Schalm's Veterinary Hematology. (5 edition) Lippincott Williams and Wilkins, Canada 1145-1146.

9. Wintrobe MM (1967) Clinical Hematology. (6 $6^{\text {th }}$ edition) Lea and Feibiger Philadelphia 415.

10. Latimer KS, Malaffey EA, Prasse KW (2003) Duncan and Prasse's Veterinary Laboratory Medicine: Clinical Pathology: Clinical Pathology ( $4^{\text {th }}$ edition) lowa State Press.

11. Bowman DD (1999) Georgis' Parasitology for Veterinarians. ( $7^{\text {th }}$ edition). WB Saunders Company.

12. State View (1993) Version 4.01. Abacaus Institute. Berkeley, California.

13. Chen L, Daugschies A, Wang B, Mao X (2000) Blood eicosanoids and immune indices during fasciolosis in water buffaloes. Vet Parasitol 49: 273-278.

14. Yadav SC, Sharma RL, Kalicharan A, Mehra UR, Dass RS et al. (1999) Primary experimental infection of riverine buffalo with Fasciola gigantica. Veterinary Parasitology 82: 285-296.

15. Spengler RN, Isseroff $H$ (1981) Fascioliasis: is the anemia caused by hematophagia? J Parasitol 67: 886-892.

16. Waweru JG, Kanyari PWN, Mwangi DM, Ngatio TA, Nansen P (1999) Comparative parasitological and hematological changes in two breeds of sheep infected with Fasciola gigantica. Tropical Animal Health and Production 31: 363-372.

17. Sanyal PK, Gupta SC (1996) Efficacy and pharmacokinetics of triclabendazole in buffalo with induced fascioliasis. Veterinary Parasitology 63: 75-82.

18. Martinez-Moreno A, Jimenez V, Martinez-Cruz MS, Martinez-Moreno FJ, Becerra $C$ et al. (1997) Anthelmintic efficacy and influence in antibody response and pathophysioloy of the disease. Veterinary Parasitology 68: 57-67.

19. Mohamed GE, EL-Sayed GR (2004) Comparative studies of closantel, triclabendazole and nitroxynil on naturally infected sheep with fasciola Mansoura Vet Med J 6: 21-37.

20. Zhang WY, Moreau E, Hope JC, Huang WY, Chauvin A (2005) Fasciola hepatica and Fasciola gigantic: comparison of cellular response to experimental infection in sheep. Experimental Parasitology 111: 154-159.

21. Bashandy MM, Yassein S, Lotfy MM, EL-Bahi M, Mohamed AM et al. (1990) Hematological and serum biochemical profiles in experimental fascioliasis in sheep. Egyptian Journal of Comparative Pathology and Clinical Pathology 3 : 357-374. 
Citation: El-Boshy ME, Husien SH, Fatma MA, Engy FR, Osama AM (2015) Comparative Studies on Triclabendazole and Mirazid in Guinea Pigs Experimentally Infected with Fasciola gigantica. J Bioanal Biomed 7: 013-017. doi:10.4172/1948-593X.1000117

22. Cervi L, Cejas H, Diana TM (2001) Cytokines involved in the immunosuppressor period in experimental fascioliasis in rats. International Journal for Parasitology 31: $1467-1473$.

23. Vengust G, Klinken M, Bidovec A, Vengust A (2003) Fasciola hepatica: effect on blood constituents and liver minerals in fallow deer (Dama dama). Veterinary Parasitology 112: 51-61

24. Gleich GJ, Adolphson CR, Leiferman KMC (1993) The biology of eosinophil leukocyte. Annu Rev Med 44: 85-101.

25. Butterworth AE, Wassom DL, Gleich GJ, Loegering DA, David JR (1979) Damage to schistosomula of Schistosoma mansoni induced directly by eosinophil major basic protein. J Immunol 122: 221-229.

26. McEwen BJ (1992) Eosinophils. A review. Vet Res Commun 16: 11-44.

27. Karen SO, Carolyn AB (1997) The enigmatic eosinophil: investigation of the biological role of eosinophils in parasitic helminth infection. Mem Inst Oswaldo Cruz 92: 93-104.

28. Elizabeth AM, Michael JH (1990) Eosinophil responses to Fasciola hepatica in rodents. International Journal for Parasitology 20: 705-708.

29. EL-Sayed MH (1997) Comparative studies on the effect of bithionol, praziqante and triclabendazole in rabbit's fascioliasis.1. Parasitological studies. J Egyp Soc Parasitol 27: 131-142.

30. Amer A, Ashraf M, Pervaiz K, Hashmi HA, Butt MYM (1998) Efficacy of triclabendazole and oxyclozamide against fascioliasis in buffaloes under field conditions. Buffalo J 3: 401-405

31. Fatem RG, Soheir MS (2003) On the efficacy of a new antischistosomal drug (mirazid) against Schistosoma haematobium and S.mansoni, An invitro study. J Egypt Ger Soc Zool 42: 89-98.

32. Motawea SM, El-Gilany A, Gaballah M, Emara F, El-Shazly AM (2001) Control of fasciola in Egyptian endemic rural area by a new safe, effective fasciolicidal herbal drug. J Environm Sci 21: 85-104

33. Qian Y, Wei HM, Ferre I, Bayonje, Mao XZ, Gonzalez GJ (1998) Plasma aspartate aminotranferase (AST), glutamate dehydrogenase (GLDH) and gamma-glutamyle transpeptidase (GGT) activities in water buffaloes with experimental subclinical fascioliasis. Veterinary Parasitology 78: 129-136.

34. Mbuh JV, Julie M (2005) Serological changes in goat experimentally infected with Fasciola gigantica in buea subdivision of S.W.P. Cameron. Veterinary Parasitology 131: 255-259.

35. Harfoush MA, Soliman HA (2003) Clinicopathological studies on fascioliasis in naturally infected cattle. Kafer EL-sheikh Vet Med J: 799-809.

36. Calleja C, Bigot K, Eckhoutte C, Sibille P, Boulard C, et al. (2000) Comparison of hepatic and renal drug-metabolising enzyme activities in sheep given single or two fold challenge infections with Fasciola hepatica. International Journal for Parasitology 30: 953-958.

37. Ahamed M, Sawsan E, Osama S, Afaf M (2001) Preliminary study of therapeutic efficacy of a new fasciolicidal drug derived from Commiphora molmol (myrrh). Am J Trop Med Hyg. 65: 96-99.

38. Scott PR, Sargison ND, Macrae, A Rhind SR (2005) An outbreak of subacute fascioliasis in Soay sheep: Ultrasonographic, biochemical and histological studies. The Veterinary Journal 170: 325-331.

39. Mayer UA, Schmid R (1978) The porphrias. In "The Metabolic Basic of Inherited Diseases". 1166-1219. McGraw-Hill, New York.

40. Lopez P, Gonzalez P, Tunon MJ, Gonzalez-Gallego J (1994) The effect of experimental fascioliasis on bilirubin metabolism in the rat. Experimental Parasitology 78: 386-393.

41. Kaneko JJ, John WH, Michael LLB (1997) Clinical Biochemistry of Domestic Animals. Academic Press, New York. 